\title{
УРОВНИ ЯЗЫКОВОЙ ЛИЧНОСТИ ОБУЧАЮЩЕГОСЯ СТАРШИХ КЛАССОВ И ЕЕ ВКЛЮЧЕННОСТЬ В УСПЕШНОСТЬ ФОРМИРОВАНИЯ ШКОЛЬНИКА КАК ВТОРИЧНОЙ ЯЗЫКОВОЙ ЛИЧНОСТИ В СИСТЕМЕ КООРДИНАТ МЕЖКУЛЬТУРНОЙ КОММУНИКАЦИИ
}

\begin{abstract}
LEVELS OF THE LANGUAGE PERSONALITY OF THE HIGH SCHOOL STUDENT AND THEIR INCLUSION IN THE SUCCESS OF ITS FORMATION AS A SECONDARY LANGUAGE PERSONALITY IN THE SYSTEM OF COORDINATES OF INTERCULTURAL COMMUNICATION
\end{abstract}

O. Nekrasova I. Mazirka

Summary: The authors of this study aim to use the descriptive method and, according to the theory of Y.N. Karaulov, to present the levels of linguistic personality (LP) involved in the characterization of high school students, as well as to outline the role of the system of these levels in determining the degree of formation of secondary linguistic personality (SLP) in high school students, while following the readiness of the latter to intercultural communication at leaving a Russian secondary school, by conducting a free association experiment. According to the results of the study, the authors conclude that the graduates of the Russian school are not prepared enough to form as SLP, and therefore demonstrate their incomplete readiness for intercultural communication.

Keywords: language personality, "secondary language personality", intercultural communication, levels of the language personality, free association experiment.
Д ля осуществления успешной коммуникации в современном мире с его постоянно меняющейся экономической и как следствие (или наоборот) тической ситуацией важно, как никогда, взаимопонимание между представителями разных национальностей; средством для такого понимания, безусловно служит язык, на котором происходит общение. Именно для успешной во всех смыслах коммуникации ее участникам недостаточно просто хорошо владеть родным или иностранным языком, немаловажно для них и «встать на одну волну», понять психологию, менталитет друг дуга и целого народа, частью которого они являются и сами, что помогает им коммуницировать и каждому, как нестранно, добиваться нужного для себя результата, идти
Некрасова Ольга Алексеевна

Аспирант, Московский государственный областной университет olynchik_86@mail.ru Мазирка Ирина Олеговна

Д.филол.н., профессор, Московский государственный областной университет mazirka_den@mail.ru

Аннотация: Авторы настоящего исследования ставят перед собой цель с помощью описательного метода и, согласно теории Ю.Н. Караулова, представить уровни языковой личности (ЯЛ), задействованные при характеристике старших школьников, а также обозначить роль системы этих уровней при определении степени сформированности у старшеклассников вторичной языковой личности (ВЯЛ), проследив при этом готовность последних к межкультурной коммуникации на выходе из российской средней общеобразовательной школы, путем проведения свободного ассоциативного эксперимента. По результатам исследования авторы делают вывод 0 недостаточности сформированности у выпускников российской школы как ВЯЛ, а следовательно, и их неполной готовности к межкультурной коммуникации.

Ключевые слова: языковая личность, вторичная языковая личность, межкультурная коммуникация, уровни языковой личности, свободный ассоциативный эксперимент.

на разумный, выгодный для обеих сторон компромисс.

Актуальность работы состоит в том, что на сегодняшний день психолингвистический аспект формирования языковой и вторичной языковой личности у старших школьников изучен недостаточно. В свою очередь, целью нашей работы является психолингвистическое исследование степени сформированности языкового сознания и вторичного языкового сознания, которое поможет определить готовность старшеклассников к межкультурной коммуникации.

Для достижения цели изыскания в нем решаются следующие задачи: 
1. описательным и сопоставительным методами дать краткий обзор работ отечественных ученых, непосредственно связанных с темой исследования;

2. с помощью описательного метода, согласно теории Ю. Н. Караулова, определить понятия «картина мира», «языковая личность» с представлением уровней последней, задействованных при характеристике и старших школьников как вторичной языковой личности (ВЯЛ) по И. И. Халеевой, в соответствии с трактовкой ученого этого явления;

3. среди российских старших школьников провести свободный ассоциативный эксперимент с использованием в нем в качестве стимулов антропонимов и понятий из сферы «общественная жизнь» и «политика», отобранных методом сплошной выборки и с помощью программного модуля сети Word Associations Network.

4. определить роль системы уровней языковой степень сформированности у старшеклассников вторичной языковой личности (ВЯЛ), а также готовность обучающихся к межкультурной коммуникации на выходе их из российской средней общеобразовательной школы.

Проблемами, связанными с изучением языковой личности (далее - ЯЛ), занимались и продолжают заниматься многие отечественные и зарубежные учёные Г.И.Богин [1], Е.М.Верещагин [2], В.В.Виноградов [3], Т.Г.Винокур [4], В.В. Воробьев [6], В.Г. Гак [8], А.А. Залевская [10], В.И. Карасик [13], Ю.Н. Караулов [14], В.Г. Костомаров [15], Т.В. Кочеткова [16], И.О. Мазирка [18,19]. Е.Д. Поливанов [22], А.А. Потебня [23], К.Ф. Седов [25], М.С. Силантьева [27], О.Б. Сиротинина [28], Флеров О.В. [31], Л.В. Щерба [34], В. Вундт [7], Г.П. Грайс [9], Дж. Остин [21], Э. Сепир [26], Б.Л. Уорф [30], Дж. Р. Ферс [35] и др. Однако в большей степени теоретической базой нашему исследованию послужили именно труды Ю.Н. Караулова по рассмотрению уровней языковой личности [14] и И.И. Халеевой [33] по изучению вторичной языковой личности и способов ее формирования.

Практическую значимость научной работы видим в возможности применения ассоциативного эксперимента в поле социолингвистики, психолингвистики, а также лингводидактики с целью изучения языковой картины мира и формирования вторичной языковой личности на разных этапах получения российскими обучающимися образования, с возможной последующей корректировкой данного процесса при подготовке россиян к успешной межкультурной коммуникации.

Сам термин «языковая личность» впервые встречается в трудах В.В. Виноградова и возник в процессе работы ученого над исследованием художественного текста [3].
Однако фундаментальное исследование данного понятия было проведено Ю.Н. Карауловым. Например, в работе «Русский язык и языковая личность» автор доказал, что понятие ЯЛ является системообразующим для описания национального языка [14].

При определении феномена «языковая личность» основным фактором (при обязательном учете всех остальных) считается принадлежность индивида к определенной культуре. Каждый в отдельности взятый язык в процессе своего развития формирует устойчивые формы общения членов социума, говорящих на этом языке, и утверждает речевые стереотипы в последнем. Таким образом, реализуется именно социальная функция языка, которая четко сигнализирует об «обслуживающем характере речевой деятельности» в целом. В социальном взаимодействии речь всегда подчинена внеречевой цели, направлена на организацию совместной деятельности людей. Разнообразные социальные роли, востребованные не только в конкретном обществе, но и в конкретный период его развития реализуются именно через общение.

Согласно заключению Ю.Н. Караулова о том, что «нельзя познать язык, не выйдя за его пределы, не обратившись к его творцу, как конкретной языковой личности» [14, с. 4], исследователь считает архиважным учитывать данные национального языка коммуниканта и информацию об истории развития общества, где последний рос и развивался, то есть этно-, социо- и психолингвистические особенности носителей национального языка, которыми этот коммуникант обладает.

Согласно Ю.Н. Караулову, существует три подхода к анализу языковой личности: «...от психологии языка и речи (изучение механизмов порождения и восприятия речи в современной психолингвистике), от закономерностей научения языку (лингводидактический подход) и от изучения языка художественной литературы» [14, c. 28]. Что касается самой языковой личности, то она также состоит из трех уровней: нулевого - структурно-языкового (ассоциативно-семантического/вербально-семантического); первого - лингво-когнитивного (когнитивного) и второго - мотивационного (мотивационно-прагматического) [14, с. 37].

Развивая концепцию «трехуровневого представления модели языковой личности» и принимая тезис о трехуровневости процессов восприятия и понимания, позже Ю.Н. Караулов скажет о конгруэнтности мотивационного, тезаурусного и вербально-семантического уровней языковой личности с выделяемыми в схеме смыслового восприятия побуждающим, формирующим и реализующим уровнями [14, с. 51], и далее ученый будет утверждать, что «Соответственно в терминах объектов, подлежащих расшифровке и пониманию на каждом 
уровне, говорят о подтексте (II), тексте (I) и словах (0)» $[14$, c. 52].

Итак, нулевой уровень - это «фонд лексических и грамматических средств, использованных личностью при порождении ею достаточно представительного массива текстов» [14, с. 36-37], где последний представляет собой «отдельные слова, стереотипные словосочетания и простые ходовые предложения» $[14$, с. 36] и, как правило, проявляется это не только в лексическом составе языка, но и в «оригинальности ассоциаций и нестандартности словосочетаний» [14, с. 52], что важно для нас при выполнении данного исследования.

Отметим, что, по Ю.Н. Караулову, «индивидуальность и субъективность могут проявиться как в вариантах иерархизации понятий и их перестановках, и противопоставлениях, так и в их соединениях при построении выводов, т.е. на субъектно-тезаурусном уровне [14, с. 52].

Именно на следующем после нулевого, первом уровне вырисовывается индивидуальная картина мира языковой личности, при этом заметим, что кардинально иной картины мира у участников внутри одного и того же социума быть не может в принципе, поскольку личность - это продукт определенного социума и, соответственно, от последнего не отделима, а при вступлении во взаимодействие с другими членами последнего ей просто необходимо обладать общими знаниями с другими членами этого социума.

Доминанта, находящаяся под сильным воздействием национально-культурных общественных традиций и идеологий, активно участвует в выделении инвариантной части данного уровня, значимой для всех носителей определенной культуры, именно эта часть и играет основную роль в понимании друг друга носителями одной культуры, поскольку характеризуется определенной национальной спецификой и находится под воздействием всей жизнедеятельности социума. При взрослении личность, чтобы обеспечивать осуществление своей успешной деятельности в обществе, усваивает опыт и приобретает знания предыдущих поколений посредством именно языка.

Первый уровень языковой личности, базирующийся на целой массе порожденных последней текстов, также помогает вычленить и вариативную часть в ее картине мира, отличную от других индивидов, при этом базовая часть картины мира должна быть обязательно известна исследователю. Деление на неизменяемую и переменную части картины или модели мира все же условно, тем не менее, универсально [14, с. 37]. На первом уровне также привлекаются экстралингвистические знания индивидума, которые расширяются последним в течение всей его жизни.
На втором уровне «языковая личность сливается с личностью в самом общем, глобальном социально-психологическом смысле и выражается в языке (текстах) и через язык в основных своих чертах» [14, с. 38].

На данном уровне реализуются коммуникативно-деятельностные потребности личности, которые диктуются экстра-, прагма- лингвистическими причинами и задаются определенными условиями сферы коммуникации, коммуникативной ситуацией и ролями коммуникантов.

Стереотип данного уровня взаимодействует с другими его элементами и отвечает коммуникативным потребностям личности.

По утверждению Ю.Н. Караулова в действительности языковая личность проявляет себя с тезаурусного уровня, поскольку только на нем «оказывается возможным индивидуальный выбор, личностное предпочтение пусть и в нешироких пределах - одного понятия другомy» $[14$, c. 52$]$.

Следует заметить, что полное описание личности возможно только согласно всем ее трем уровням одновременно. В центре интересов данного исследования находится именно первый уровень, где происходит «реконструкция языковой картины мира (тезауруса) путем анализа произведенных ею текстов или через специальное тестирование» [14, с. 45] (в нашем случае через проведение свободного ассоциативного эксперимента).

Важной составляющей данного эксперимента стало выяснение по Ю.Н. Караулову, связи уровней языковой личности (нулевого и первого) с обязательным учетом языковой социализации последней и ее «приобщения к общественным стереотипам и господствующим идеям, и понятиям» $[14$, с. 45$]$.

ЯЛ есть личность, выраженная в языке и через язык, реконструированная в основных своих чертах на базе языковых средств [14, с. 38].

Согласно другому ученому, И.И. Халеевой, «язык может использоваться и используется для социализации «картин мира», содержащихся в индивидуальных концептуальных системах, для приближения их к «картине», разделяемой членами языкового сообщества и отвечающей их ориентационным и экзистенциональным (физическим, духовным, технологическим, этическим, эстетическим и др.) потребностям в мире» [33, с. 54].

Акт рецепции в пределах социокультурного пространства реципиента этого акта «требует обращения к... знаниям о мире. Это касается и обыденного употребления языка - в целях коммуникации, - и необыденного, надкоммуникативного его употребления - в целях 
познания и воздействия» [14, с. 65].

По утверждению И.И. Халеевой, при формировании «вторичной» языковой личности посредством изучения ее текстовой деятельности с инофоном следует учитывать сложность при «преодолении культурологической дистанции между коммуникантами» [33, с. 64].

Обучающийся иностранному языку, переходя на тезаурусный уровень своего развития как языковой личности, должен обязательно обладать некими знаниями о картине мира другой языковой общности [33, с. 58].

По мнению другого исследователя, О.Л. Каменской, тезаурусом называют «некоторую универсальную систему, обеспечивающую хранение коллективного (для того или иного социума) знания о мире в вербальной форме» $[12$, c. 232].

М.А. Волькенштейн считает, что под тезаурусом следует понимать «все интеллектуальное и эмоциональное богатство рецептора, включающее его способность к сотворчеству» $[5$, с. 73].

По мнению И. И. Халеевой, именно на тезаурусном уровне возникает возможность для формирования «вторичной языковой личности», при этом под тезаурусом - I, ученый понимает «способ формирования языкового сознания, восходящего к языковой картине мира, и тем самым напрямую связанный с ассоциативно-вербальной сетью языка, в отличии от тезауруса - II, который соотносится собственно со знаниями о мире (не всегда находящими непосредственную корреляцию в словарном фонде), формирующими когнитивное сознание и тем самым общую картину мира на уровне концептуальной системы, в частности как системы пресуппозиций и импликаций. Источниками тезауруса - II выступают и чувственный опыт, и деятельность, отраженные в текстах» [33, с. 76], и оба тезауруса носят как объективированный, так и субъективированный (субъектный) характер [33, с. 77].

Взаимосвязь и взаимозависимость обоих тезаурусов происходит благодаря социальной повторяемости акта познания и социальному опыту самой личности, ее мотивам и ценностным ориентирам [33, с. 77].

Субъективированность языковой картины мира происходит через текст(ы) с объективированием в нем(них) тезауруса-словаря и энциклопедического знания языковой личностью мира [33, с. 77].

Практически любая текстовая деятельность - это результат общения индивидумов в социуме, в которой представлен накопленный членами общества коммуниканта опыт, в том числе и языковая семантика, благодаря чему возможно формирование не только языкового, но и когнитивного сознания языковой личности (в том числе и вторичной) [33, с. 78], доказательство чего стало также одной из целей нашей работы.

Для подтверждения проанализированного нами теоретического знания о языковой личности и «вторичной языковой личности» на практике нами был проведен свободный ассоциативный эксперимент среди обучающиеся 9-х, 10-х и 11-х классов (всего 100 человек) в одной из средних общеобразовательных школ Московской области, с целью изучения языковой картины мира русскоговорящих старших школьников, которая формируется у них из совокупности психических механизмов порождения, понимания речи и хранения языка в их сознании. Одной из целей эксперимента стало изучение особенностей восприятия данной группой информантов антропонимов - стимулов и понятий-стимулов из ассоциативного ряда «политика» и «общество». Далее был выполнен анализ ассоциативных полей (слов/словосочетаний - реакций) этих информантов на предмет выяснения степени сформированности их как вторичной языковой личности на выходе из российской средней образовательной школы).

Для выявления наиболее известных современному носителю русского языка (из числа старших школьников) единичных имен собственных или совокупностей имен собственных, идентифицирующих человека, т.е. антропонимов из области политики и общественной жизни в целом, на первом этапе эксперимента испытуемым (всего 30 человек) было предложено назвать имя широко известной публичной личности, относящейся к сферам «общественная жизнь» и «политика», при этом данная кандидатура при внесении в список антропонимов-стимулов должна была удовлетворять следующим условиям:

1. известность для современного носителя языка;

2. заметная роль предлагаемого лица в политике и в жизни общества;

3. предполагаемый значительный смысловой объем имени;

4. возможная неоднозначность отношения к носителю данного имени в обществе.

По результатам опроса 30 информантов был составлен список антропонимов-стимулов для проведения второго этапа эксперимента. Всего было выделено 30 антропонимов, и в список для эксперимента вошли следующие политические и общественные деятели (представлены в порядке убывания известности у респондентов): 1. В.В. Путин, 2. Дональд Трамп, 3. Барак Обама, 4. Д.А. Медведев, 5. Джордж Вашингтон, 6. Л.И. Брежнев, 7. Адольф Гитлер, 8. Гай Юлий Цезарь, 9. Владимир Жириновский, 10. Геннадий Зюганов, 11. Маргарет Тэтчер, 12. Томас Вудроу, 13. Елизавета II (королева Англии), 14. Николя Саркази, 15. Петр I, 16. Екатерина II, 17. Иван 
Грозный, 18. Сергей Лавров, 19. Сергей Шойгу, 20. Рамзан Кадыров, 21. Фидель Кастро, 22. Хиллари Клинтон, 23. Петр Порошенко, 24. Николай II, 25. Иосиф Сталин, 26. В.И. Ленин, 27. Борис Джонсон, 28. А. Лукашенко, 29. Ангела Меркель, 30. Грета Тунберг.

Заметим сразу, что только 9 из 30 предложенных школьниками имен принадлежали деятелям из англоязычных стран, хотя эксперимент проводился учителем английского языка и на занятии по соответствующему предмету, поэтому, согласно целям исследования, приведем ниже анкеты по девяти англоязычным политическим и общественным деятелям.

Barack Obama (100) USA (США) 66, NATO (HATO, Ceвероатлантический Союз) 14, White House (Белый Дом) 6, Libya (Ливия) 5, A strict policy towards Russia (Жесткая политика в отношении России) 4, Nobel Peace Prize (Hoбелевская премия мира) 2, Black (Черный) 2, Folly (Безрассудство) 1.

Boris Johnson (100) The Prime Minister of the United Kingdom (Премьер-министр Великобритании) 29. Brexit (Брексит) 27, COVID-19 (Коронавирус) 25, Conservative party (Консервативная партия) 10, Blows hot and cold (Постоянно меняет свою точку зрения) 9.

Donald Trump (100) America (Америка) 73, Business (Бизнес) 12, Republican Party (Республиканская партия) 8, Twitter (Твиттер) 5, Melania Trump (Мелания Трамп) 2.

Elizabeth II (the Queen of the United Kingdom) (100) Monarchy (Монархия) 33, Buckingham Palace (Букингемский дворец) 26, Reunification (Воссоединение) 14, European Union (Европейский Союз) 11, Charity (Благотворительная деятельность) 7, Winston Churchill (Уинстон Черчилль) 5, Charles, Prince of Wales (Чарльз, принц Уэльский) 2, Facebook (Фейсбук) 1, Does not affect the governance of the country (Не оказывает влияния на управление страной) 1.

George Washington (100) The first President of the USA (Первый президент США) 53, Statesman (Государственный деятель) 31, Thanksgiving Day (День благодарения) 6, Navy (Военно-морской флот) 6, Father of his country (отец своей страны) 4.

Greta Thunberg (100) Ecology (Экология) 59, Environmental protection (Защита окружающей среды) 17, School strikes for climate (Школьные забастовки за климат) 9, Global Warming (Глобальное потепление) 7, Sweden (Швеция) 3, Protest (Протест) 3, Student (Ученица) 1, United Nations organization $(\mathrm{OOH}) 1$.

Hillary Clinton (100) The USA (США) 30, Politician (Политик) 18, Presidential candidate (Кандидат в президенты)
16, Fracas (Скандал) 14, Hates Russia (ненавидит Рocсию) 11, Bill Clinton's wife (Жена Билла Клинтона) 5, FBI (ФБР) 5, Unpleasant person (Неприятная особа) 1.

Margaret Thatcher (100) United Kingdom (Великобритания) 26, Prime Minister (Премьер-министр) 24, Iron Lady («Железная Леди») 19, The first woman to become Prime Minister (Первая женщина, которая стала премьер-министром) 15, Thatcherism (Тетчеризм) 6, Reforms (Реформы) 5, London (Лондон) 3, The Privy Council of the United Kingdom (Тайный Совет Великобритании) 1, Mikhail Gorbachev (Михаил Горбачев) 1.

Thomas Woodrow (100) The First World War (Первая мировая война) 5, President of USA (Президент США) 20, Paris peace conference (Парижская мирная конференция) 20, The Fourteen Points («Четырнадцать пунктов») 18, Democratic party (Демократическая партия) 15, The failure of the League of Nations (Провал Лиги Наций) 2.

Нами также были предложены школьникам для получения реакций с их стороны (без какого-либо времени на обдумывание своего ответа) следующие политические и общественные термины и понятия-стимулы: Асаdemic education, anarchy, capitalism, communism, corruption, critique, democracy, diaspora, diplomacy, domination, electorate, faction, fascism, foray, imperialism, intellectual, intrigue, islamist, journalism, kingship, lobbying, mainstream, marxism, military, participation, party, philosophy, populist, presidency, progressive, racism, radical, reform, Religion, Republican, Rhetorics, statesman, socialism (всего 38 понятий-стимулов).

Приведем ниже анкеты реакций по 38 понятиям-стимулам.

Academic education (100) Academy of Sciences (Академия наук) 23, Progress (Прогресс) 22, Lomonosov Moscow state University (Мгу им. М.В. Ломоносова) 20, PhD (Кандидат наук) 14, Аcademician (Академик) 11, Higher education (Высшее образование) 10.

Anarchy (100) Chaos (Хаос) 28, Disorder (Беспорядок) 26, Lawlessness (Беспредел) 24, Revolution (Революция) 20, Bakunin (Бакунин) 2.

Capitalism (100) Karl Marx (Карл Маркс) 33, Capital (Капитал) 26, Exchange relations (Рыночные отношения) 17, Proletariat (Пролетариат) 15, Capital profit (Капитальная прибыль) 9.

Communism (100) CPSU (KПСС) 36, Zyuganov (3юганов) 32, Party member (Партиец) 11, USSR (CCCP) 8, Soviet government (Советская власть) 7, Social equality (Социальное равенство) 4, Politburo (Политбюро) 2. 
Corruption (100) Government of the Russian Federation (Правительство РФ) 48, Ministers (Министры) 17, Bribes (Взятки) 15, Oligarch (Олигарх) 7, Alexey Kuznetsov (Алексей Кузнецов) 6, Alexey Ulyukayev (Алексей Улюкаев) 4, Venality (Продажность) 3.

Critique (100) Politics (Политика) 26, Mass media (Средства массовой информации) 25, Орposition (Оппозиция) 23, Ksenia Sobchak (Ксения Собчак) 16, Alexey Navalny (Алексей Навальный) 8, Review (Рецензия) 2.

Democracy (100) Government of the Russian Federation (Правительство РФ) 19, Реорle (Народ) 18, Democratic party (Демократическая партия) 17, Political system (Политическая система) 16, President (Президент) 12, ‘United Russia’ («Единая Россия») 12, Aristocracy (Аристократия) 5, Authoritarian (Авторитарная) 1.

Diaspora (100) Ethnos (Этнос) 27, Jewish (Еврейская) 25, Israel (Израиль) 22, Historical motherland (Историческая Родина) 19, Armenia (Армения) 7.

Diplomacy (100) UN Security Council (Совбез ООН) 18, International policy (Внешняя политика) 16, Sergey Lavrov (Сергей Лавров) 16, Negotiations (Переговоры) 14, Primakov (Примаков) 14, Foreign languages (Иностранные языки) 12, the Embassy of the Russian Federation (Посольство РФ) 10.

Domination (100) Control (Управление) 23, Obedience (Послушание) 20, ‘United Russia' («Единая Россия») 17, Leadership of Russia (Руководство России) 15, Hierarchy (Иерархия) 11, The USA (США) 10, Xi Jinping (Си Цзиньпин) 4.

Electorate (100) Voter (Избиратель) 32, Election (Выборы) 25, Party (Партия) 24, Deputy (Депутат) 12, Zhirinovsky (Жириновский) 7.

Faction (100) Policy (Политика) 26, The State Duma (Государственная Дума) 20, Party (Партия) 19, Left-wing faction (Левая фракция) 12, Anti-party (Антипартийная) 9, Opposing (Враждующая) 7, 'The United Russia' («Единая Россия») 7.

Fascism (100) Germen (Немцы) 19, Adolf Hitler (Адольф Гитлер) 17, Nazism (Нацизм) 15, Fuhrer (Фюрер) 14, War (Война) 13, Death camp (Лагерь смерти) 12, Violence (Насилие) 10.

Foray (100) Surprise attack (Неожиданное нападение) 32, Capture (Захватывать) 27, A short-term intrusion (Кратковременное вторжение) 21, Crime (Преступление) 15, Junta (Хунта) 4, Prophetic Oleg (Вещий Олег) 1.

Imperialism (100) Foreign policy (Внешнеполитиче- ский) 36, Military power (Военная сила) 24, Political and economic control (Политический и экономический контроль) 20, NATO (НАTO, Североатлантический Союз) 16, Capture of territories (Захват территорий) 4.

Intellectual (100) Smart (Умный) 25, Vladimir Putin (Владимир Путин) 20, Edward Snowden (Эдвард Сноуден) 17, Wise (Мудрый) 15, Sergey Lavrov (Сергей Лавров) 15, Success (Успех) 6, Composure (Самообладание) 2.

Intrigue (100) Political intrigues (Политические интриги) 22, Black Public Relations (BPR) (Черный пиар) 18, Machination (Махинация) 17, Collusion (Заговор) 16, Release of negative information (Выброс негативной информации) 10, Hillary Clinton vs. Donald Trump (Хиллари Клинтон против Дональда Трампа) 9, Camilla ParkerBowles (Камилла Паркер-Боулз) 4, The plot against the Russian Orthodox Church in Ukraine (Заговор против Русской православной церкви на Украине) 3, Conspiracy against humanity (Заговор против человечества) 1.

Islamist (100) Terrorism (Терроризм) 40, War (Война) 36, Religion (Религия) 13, Islam (Ислам) 11.

Journalism (100) Mass media (Средства массовой информации) 26, Free speech (Свобода слова) 17, CNN International (Си-Эн-Эн Интернешнл) 14, Global (Глобальная) 12 , Influence on the political process (Влияние на политический процесс) 12, BBC World (Би-би-си) 10, Audience (Аудитория) 9.

Kingship (100) Peter I (Петр I) 26, Ivan the Terrible (Иван Грозный) 23, Catherine II (Екатерина II) 20, Nikolay II (Николай II) 18, The United Kingdom (Соединенное Королевство) 13.

Lobbying (100) Deputy (Депутат) 31, Corruption in Russia (Коррупция в России) 29, Oligarch (Олигарх) 24, Government support (Государственная поддержка) 16.

Mainstream (100) Political magazine (Политический журнал) 34, World development (Мировое развитие) 30, Be in the trend (Быть в тренде) 22, Tendency (Тенденция) 14.

Marxism (100) Theory of scientific communism (Teoрия научного коммунизма) 21, Lenin (Ленин) 20, Marx and Engels (Маркс и Энгельс) 17, A teaching about reality (Учение о действительности) 15, Political current (Политическое течение) 14, Marxist philosophy (Марксистская философия) 13.

Military (100) Army (Армия) 30, Sergei Shoigu (Сергей Шойгу) 28, Russian nuclear weapons (Российское ядерное оружие) 27, Power (Сила) 9, Kim Jong-un (Ким Чен Ын) 6. 
Participation (100) Senate (Сенат) 22, Take a decision (Принимать решение) 19, Political (Политическое) 17, Oksana Moroz (Оксана Мороз) 16, Participation in financing (Участие в финансировании) 14, Foreign (Иностранное) 12.

Party (100) The State Duma (Государственная Дума) 21, The 'United Russia' («Единая Россия») 18, Republican Party (Республиканская партия) 15, Democratic Party (Демократическая партия США) 14, LDPR (ЛДПР) 11, Whigs («Виги») 9, Tory («Тори») 7, To join a party (Вступать в партию) 5.

Philosophy (100) Consciousness (Сознание) 35, Science (Наука) 17, Aristotle (Аристотель) 15, Materialism (Материализм) 13, Plato (Платон) 12, Ancient philosophy (Античная философия) 8.

Populist (100) - Demagogy (Демагогия) 26, Idle talk (Пустая болтовня) 22, Politician (Политик) 19, Flirting (Заигрывание) 16, Empty promise (Пустое обещание) 15, Alexey Navalny (Алексей Навальный) 2.

Presidency (100) Putin (Путин) 27, President (Президент) 24, Government (Государственная власть) 21, State (Государство) 20, The Kremlin (Кремль) 4, Barack Obama (Барак Обама) 3, Alexander Lukashenko (Александр Лукашенко) 1.

Progressive (100) Progressive policy (Прогрессивная политика) 34, Тах (Налог) 29, Growth of unemployment in Russia (Рост безработицы в России) 19, Progressive mankind (Передовое человечество) 18.

Racism (100) Fascism (Фашизм) 35, Nazism (Нацизм) 30, The eradication of the nation (Искоренение нации) 18, Genocide (Геноцид) 17.

Radical (100) Decisive actions (Решительные действия) 23, Revolution (Революция) 21, Free (Свободный) 19, Nationalists (Националисты) 16, Armed resistance (Boоруженное сопротивление) 14, Maidan (Майдан) 6, People who want to change (Люди, которые хотят что-то изменить) 1.

Reform (100) Political (Политическая) 22, Education reform (Реформа образования) 18, Currency (Денежная) 15, Law (Закон) 14, President (Президент) 11, Peter Stolypin (Петр Столыпин) 9, Ministry of Education (Министерство образования) 6, Reformation (Преобразование) 5.

Religion (100) Orthodox religion (Православие) 23, Faith (Вера) 22, God (Бог) 20, Church (Церковь) 17, Governmental support (Государственная поддержка) 11, Bible (Библия) 6, Miraculous power (Чудодейственная сила) 1.

Republican (100) Party (Партия) 23, Conservative (Кон- сервативный) 20, Senator (Сенатор) 19, Donald Trump (Дональд Трамп) 16, Democracy (Демократия) 13, Aggressive foreign policy (Агрессивная внешняя политика) 9.

Rhetoric (100) Methods of persuasion (Методы убеждения) 24, Culture of speech (Культура речи) 22, Orator (Оратор) 16, Express thoughts (Выражать мысли) 15, V. I. Lenin (В.И. Ленин) 13, Public statements (Публичные высказывания) 10.

Statesman (100) Politician (Политик) 26, Conspicuous (Выдающийся) 18, Vladimir Putin (Владимир Путин) 18, Muammar Gaddafi (Муаммар Каддафи) 11, Joseph Stalin (Иосиф Сталин) 9, The President (Президент) 6, Donald Trump (Дональд Трамп) 4, Winston Churchill (Уинстон Черчилль) 4, Mahatma Gandhi (Махатма Ганди) 4.

Socialism (100) Social structure (Социальный строй) 27, Overthrow of capitalism (Свержение капитализма) 26, Ideology (Идеология) 17, Utopia (Утопия) 16, Social equality (Социальное равенство) 14.

Родным языком (или первым) для всех испытуемых был русский язык, но поскольку одной из целей работы было рассмотрение вопроса, связанного с развитием вторичного языкового сознания у русскоговорящих обучающихся старшей школы, то последним было в качестве рекомендации предложено (но не строго) по возможности отвечать на английское слово-стимул также реакцией на английском языке. Форма проведения эксперимента - письменная.

При обработке полученных данных подсчитывалась частотность реакций, данных испытуемыми на тот или иной стимул, в результате чего из слов-реакций формировалось ассоциативное поле последнего, позже реакции выстраивались по принципу убывания их частотности на это слово-стимул, с указанием этих данных (соответствующей цифрой) в единицах в колонке после слова-стимула.

При одинаковой частотности реакций, данных испытуемыми, первые представлялись в алфавитном порядке. Принятых отказов на репрезентацию какой-либо ассоциации (реакции) на слово-стимул не наблюдалось.

В результате проведенного исследования выяснилось, что у школьников при даче реакций практически в каждом из 38 понятий-стимулов присутствовали в качестве приоритетных реакции через призму менталитета россиянина, то есть через призму своего «я» и общества, где испытуемый растет и развивается (164 из 597). Далее, обучающиеся в основном (через синонимы) давали реакции на понятия-стимулы (63 из 597). С точки зрения научного объяснения последних, реакций было мало (17 из 597), при этом ответы школьников были заметно об- 
условлены личным отношением испытуемых к явлениям из общественной или политической жизни (116 из 398), или к самой политической персоне (101 из 199), поэтому оценки испытуемых были субъективно-объективными. К тому же старшие школьники продемонстрировали наличие у них достаточного опыта в суждениях относительно политики и общественной жизни в целом, однако чрезвычайно редко связывали термины-стимулы с жизнью и персонами в англоговорящих странах (27 из 597).

Следует заметить, что многие антропонимы-стимулы воспринимались обучающимися в неразрывной связи с другими антропонимами и понятиями-стимулами, поскольку политическая и общественная жизнь представлялась им неким целым, что означает, что элементы языковой картины мира обучающихся не находятся в отрыве друг от друга, а постоянно взаимодействуют.

Полученные результаты помогли сформировать следующие выводы.

В ходе решения задач №1 и №2 выяснено, что сформированность нулевого уровня ЯЛ (по Ю.Н. Караулову) наших испытуемых четко доказывает их принадлежность к российскому обществу и то огромное влияние, которое последнее (его СМИ, школьная программа) оказывают на формирование картины мира личности обучающихся.

При решении задачи № 2 была еще раз подтверждена точка зрения Ю.Н. Караулова, что кардинально иной картины мира у участников внутри одного и того же социума быть не может (инвариантная часть), отмечается заметная посвященность обучающихся в поле отношений «к общественным стереотипам и господствующим идеям и понятиям» в российском обществе, однако именно на первом уровне формирования ЯЛ в картине мира у ряда информантов можно было вычленить вариативную часть, где отчетливо прослеживались их экстралингвистические знания (межпредметные связи).

Решение задачи №3 доказало, что без направленности проведения эксперимента, обучающиеся продемонстрировали по большей части накопленный членами общества, к которому они принадлежат, опыт, в том числе и правильное усвоение языковой семантики, благодаря чему у них сформировалось языковое и когнитивного сознание как языковой личности (в том числе и отчасти вторичной). Однако в процессе формирования своей вторичной языковой личности обучающиеся не показали безусловную успешность формирования у них ассоциативно-вербальной сети изучаемого языка или она была незначительной по объему (Тезаурус 1). Тезаурус 2 в данном контексте (знания о мире, формирование когнитивного сознания, картина мира на уровне концептуальной системы (пресуппозиций и импликаций) был выражен более ярко в реакциях на антропонимы-стимулы, однако при их отборе в первой части эксперимента, также была заметна недостаточная степень сформированности обучающихся как вторичных языковых личностей.

Решение задачи №4 говорит о правильном векторе в осуществлении межпредметных связей в образовательных программах средних общеобразовательных школ РФ, но не является весомым доказательством формирования вторичного языкового сознания у выпускников средней общеобразовательной школы в РФ. Само проведение исследования на уроке английского языка, выделение экспериментатором слов-стимулов на английском языке и его просьба по возможности давать реакции также на английском языке не стали каким-либо заметным стимулом для испытуемых (всего на английском языке было дано 280 реакций из 597). Отсюда авторами делается вывод о недостаточности сформированности выпускников российской школы как ВяЛ, а, следовательно, и их неполной готовности к межкультурной коммуникацию на выходе обучающихся из средней образовательной российской школы.

Перспективу дальнейших исследований видим для себя в проведении теперь направленного ассоциативного эксперимента, с целью выявить степень успешности формирования ВЯЛ старших школьников на уровнях тезауруса 1, 2 или на втором уровне ЯЛ, где должны реализовываться ее коммуникативно-деятельностные потребности, которые нами намеренно не были созданы В проведенном эксперименте.

\section{ЛИТЕРАТУРА}

1. Богин Г.И. Языковая личность школьника как формат для определения успешности его филологической подготовки. (Пособие для методиста и учителя). Часть 1 [Электронный ресурc]. URL: https://b-ok.com/book/3162805/742483 (дата обращения: 28.09.2020).

2. Верещагин Е.М., Костомаров В.Г. Язык и культура. М: Индрик, 2005. 1040 c.

3. Виноградов В.В. Избранные труды: 0 языке художественной прозы. М.: Наука, 1980.360 с.

4. Винокур Т.Г. Говорящий и слушающий [Текст]: варианты речевого поведения / Т.Г. Винокур; вступ. ст. Л.П. Крысина. - Изд. 5-е. M.: URSS, сор. 2016.172 с.

5. Волькенштейн M.А. Стихи как сложная информационная система // Наука и жизнь. М.: Правда, 1970. № 1. [Электронный pecypc]. URL: https://www.litmir. $\mathrm{me} / \mathrm{br} / ? \mathrm{~b}=84808 \& \mathrm{p}=2$ (дата обращения: 30.09 .2020 ). 
6. Воробьев В.В. Языковая личность в лингвокультурологии // Языковая личность: Лингвистика. Лингвокультурология. Лингводидактика: Матер. Всеросс. научно-методической конф. Уфа: РИЦ БашГУ, 2011. С. 234-237.

7. Вундт В. Проблемы психологии народов. СПб.: Питер, 2001. 160 с.

8. Гак В.Г. Сопоставительная лексикология: на материале французского и русского языков. Изд. 2-е. М.: Либроком, 2010. 264 с.

9. Грайс Г.П. Логика и речевое общение // Межличностное общение: хрестоматия: [невербальная коммуникация, мужской и женский стили общения, манипуляции в межличностном общении, аксиомы межличностной коммуникации, речь в межличностном общении] / сост. Н.В. Казаринова, В.М. Погольши. СПб.: Питер, 2001. С. 171-194.

10. Залевская А.А. Психолингвистические исследования. Слово. Текст: Избранные труды. М.: Гнозис, 2005. 543 с.

11. Иванова С.В., Чанышева 3.3. Лингвокультурология: проблемы, поиски, решения. Уфа: РИЦ БашГУ, 2010. 366 с.

12. Каменская 0.Л. Компоненты семантической структуры текста: диссертация ... доктора филологических наук: 10.02.19. Москва, 1988. 393 с.

13. Карасик В.И. Языковой круг: личность, концепты, дискурс / В.И. Карасик; Науч.-исслед. лаб. «Аксиол. лингвистика». М.: ГН03ИС, 2004. 390 с.

14. Караулов Ю.Н. Русский язык и языковая личность. Издание 7-е. М.: Издательство ЛКИ, 2010. 264 с.

15. Костомаров В.Г. Наш язык в действии: очерки соврем. рус. Стилистики / В.Г. Костомаров. М.: Гардарики, 2005. 287 с.

16. Кочеткова Т.В. Языковая личность носителя элитарной речевой культуры: автореф. дис. . . . д-ра филол. наук. Саратов, 1999. 53 с.

17. Красных В.В. Виртуальная реальность или реальная виртуальность? (Человек. Сознание. Коммуникация). М.: Диалог-МГУ, 1998. 352 с.

18. Мазирка И.О. Концептуальная структура социально-конструктивной языковой личности и языковой картины мира героя художественной литературы// Проблемы психолингвистики, интерпретации текста и теории коммуникации. Сборник научных трудов. М.: МГОУ, 2006. С. $28-31$.

19. Мазирка И.О. Лингвополитическая концептосфера, личностные концепты и языковая картина мира героя художественной литературы в процессе взаимодействия с макросоциумом // Проблемы психолингвистики, интерпретации текста и теории коммуникации. Сборник научных трудов. М.: Мгоу, 2006. C. 18-23.

20. Маслова В.А. Лингвокультурология. М.: Издательский центр «Академия», 2001. 208 с.

21. Остин Джон. Избранное /Перевод с англ. Макеевой Л.Б., Руднева В.П. Издательство: М.: Идея-Пресс, Дом интеллектуальной книги, 1999.332 с.

22. Поливанов Е.Д. Статьи по общему языкознанию: Избранные работы. М: Наука, 1968. 376 с.

23. Потебня А.А. Мысль и язык [Текст] / А.А. Потебня. М.: Лабиринт, 2007. 248 с.

24. Прохоров Ю.Е. В поисках концепта. М.: Флинта: Наука, 2009. 176 с.

25. Седов К.Ф. Становление структуры устного дискурса как выражение Становление структуры устного дискурса как выражение эволюции языковой личности: дис. ... д-ра филол. наук. Саратов, 1999. 436 с.

26. Сепир Э. Избранные труды по языкознанию и культурологии. М.: Издательская группа «Прогресс», 1993.656 с.

27. Силантьева М.С. Элитарная языковая личность в профессиональном дискурсе: автореф. дис. ... к-та филол. наук. Пермь, 2012.18 с.

28. Сиротинина 0.Б. Русский язык: система, узус и создаваемые ими риски: [монография] / 0.Б. Сиротинина; Саратовский гос. ун-т им. Н.Г. Чернышевского. Саратов: Изд-во Саратовского ун-та, 2013. 115 с.

29. Тхорик В.И., Фанян Н.Ю. Лингвокультурология и межкультурная коммуникация. М.: ГИС, 2006. 260 с.

30. Уорф Б.Л. Наука и языкознание. Новое в лингвистике. Вып. 1. [Электронный ресурс]. URL: http://philology.ru/linguistics1/worf-60a.htm (дата обращения: 20.09.2020).

31. Флеров 0.В., Алямкина Е.А. Вторичная языковая личность и её развитие в учебном процессе // Психология и Психотехника. [Электронный ресурс]. URL: https://nbpublish.com/library_read_article.php?id=27070 (дата обращения: 15.09.2020).

32. Фомина Ю.С. Языковая личность студента полиэтнического вуза: дис. к-та филол. наук, Уфа, 2011. 237 с.

33. Халеева И.И. Основы теории обучения пониманию иноязычной речи (подготовка переводчиков). М.:- Высшая школа, 1989. 238 с.

34. Щерба Л.В. Языковая система и речевая деятельность. Изд. 2-е, стереотипное. М.: Едиториал УРСС, 2004. 432 с.

35. Firth J.R. The tongues of men, and Speech. London: Oxford University Press, 1964. 211 p.

( ) Некрасова Ольга Алексеевна (olynchik_86@mail.ru), Мазирка Ирина Олеговна (mazirka_den@mail.ru).

Журнал «Современная наука: актуальные проблемы теории и практики» 